\title{
Social Aspects of Learning: Sámi People in the Circumpolar North
}

\author{
Outi Kaarina Laiti \\ University of Lapland \\ Finland \\ Satu-Maarit Frangou \\ University of Lapland \\ Finland
}

ABSTRACT: This article addresses how, in the Arctic regions, indigenous traditional educational approaches focus on the cultural background of the people and their social learning customs in today's context. The development of Arctic pedagogical approaches is discussed in light of experiences collected in Finnish Lapland in 2017 with the Sámi people. Particularly, the significance of social interactions in indigenous pedagogies is explored. We ask how social interactions benefit technologically enhanced learning in the Sámi cultural context. The findings suggest that social interactions have the potential for improving learning even when learning with and through information and communication technologies (ICTs).

KEYWORDS: social learning, Arctic pedagogy, Sámi pedagogy, Sámi education, Finland

\author{
Social Learning in Sámi and Arctic Pedagogies \\ Research Context: Game Programming with Sámi Adolescents \\ Methodology \\ Ethical Issues and Limitations \\ Findings \\ Discussion, Implications, and Future Research \\ References \\ Author Contact
}

This article explores developing Arctic and Sámi pedagogical approaches and attempts to investigate the social aspects of learning in an indigenous ecological context and environment when learning with and through information and communication technologies (ICTs). In addition, it seeks to determine what types of empirical studies are needed for the further development of Arctic and Sámi pedagogies. The study combines indigenous Sámi and Arctic pedagogies, since the latter pays attention to people living in the Arctic and the special conditions that the Arctic raises for educational solutions. Arctic pedagogy makes use of new technologies and social media for its further development (Määttä \& Uusiautti, 2015). Sámi pedagogy, in contrast, denotes a pedagogical model based 
on the history, traditions, and special features of Sámi culture. Sámi pedagogy has a holistic and constructivist approach to learning (Keskitalo, Uusiautti, \& Määttä, 2012). Many people in Arctic areas have an indigenous background, and togetherness is a vital component of indigenous pedagogies (Balto, 1997; Smith, 1999), such as Sámi. Indigenous pedagogy is a pedagogical approach that does not lean on a European knowledge system or written texts. Instead, it promotes indigenous knowledge and ways of learning (Battiste, 2002).

The Arctic poses challenges to educational providers, such as the need to travel long distances, multiple and challenging contexts, and a harsh climate; to some extent, these challenges can be overcome via ICT and media (Rasi, Keskitalo, \& Rasmus-Moilanen, 2016). The use of ICT and media can combat the challenges of the North; however, they can also simultaneously create an "other" since the togetherness of the learning moment can be lost somewhere between a network connection and a virtual classroom. Hence, the use of ICT needs to be carefully planned so that, for example, the togetherness of the learning moment is not lost during distance learning. For a successful distance learning pedagogy in general, sociality and learning together are essential. Social interaction has the power to cut the "distance" in distance learning (Boling, Hough, Krinsky, Saleem, \& Stevens, 2011; Hernández-García, González-González, Jiménez-Zarco, \& Chaparro-Peláez, 2015).

Meltzoff, Kuhl, Movellan, and Sejnowski (2009), among others, explain that there are three essential and natural social skills for human development: imitation, shared attention, and empathy with social emotions. Hence, this study is interested in creating a pathway through which social learning on digital learning platforms in the development of Arctic and Sámi pedagogies can be considered. This is accomplished through a discussion of the results of an empirical study conducted in Finnish Lapland in 2017 with a group of Sámi people. The article also explains what types of empirical research are necessary for this kind of development. The study was based on open-ended interviews, conducted with three people responsible for a 2017 game programming course for youths (aged 6-17 years) in Lapland, about their observations of social learning in the Arctic context. Due to the specific context and research subjects' background, this study concentrates on and explores Sámi and Arctic pedagogies. However, this does not limit the possible transferability or applicability of the results to other indigenous environments and educational programming.

\section{Social Learning in Sámi and Arctic Pedagogies}

The three natural social skills mentioned above are considered vital for human development. Imitation, first, and shared attention, second, are skills that allow people to direct their attention toward the same objects as others around them, as well as imitate others' actions. Third, people have the skill of empathy with social emotions, meaning that they comprehend other people's feelings (Meltzoff et al., 2009). Children start learning by observing and then imitating the 
people around them, beginning with facial expressions, which continues into adulthood (Ratcliffe, 2006). Imitative learning motivates and quickens learning, simultaneously offering a multitude of learning opportunities. Furthermore, the observer needs to understand the meaning of gestures to have the motivation to imitate them (Ratcliffe, 2006).

People learn with and from each other. Research has shown that social interactions involve brain areas and mechanisms that assist and support learning by strengthening learning experiences, consequently making them more memorable. Interestingly, social learning is also supported by a shared brain system for action support and perception (Dubinsky, Roehrig, \& Varma, 2013; Lipina \& Roder, 2012; Meltzoff et al., 2009). At the same time, Immordino-Yang (2011) argues that cognition and emotion, and thus the brain and mind, are interconnected. Hence, by processing social events, we learn through deciphering the actions and feelings of the people around us. Lipina and Roder (2013) further pointed out that even playing music becomes more accurate when people perform together rather than playing in solitude.

A neuroimaging study using functional magnetic resonance imaging (fMRI) has suggested an alternative explanation for the mnemonic system. During memorization, the left inferior frontal gyrus and medial temporal lobe have historically been associated with memory encoding. However, during the social encoding condition, the encoding activity occurs in the dorsomedial prefrontal cortex (DMPFC), which is not considered a traditional memory region (Lieberman, 2012). This means that memories associated with a social context and those with an academic context may be stored differently. When academic work is accomplished through social interaction, a different brain area encodes the memories. Hence, it could be beneficial to establish socially motivating learning contexts that encourage the mastering of academic content in social interactions. This study can have important educational and epistemological implications if it is true that another mnemonic system can be utilized for the better retention of knowledge. It is also notable that oxytocin (neuronal signaling molecules affecting brain activity) has memory-impairing effects for nonsocial information, whereas it has memory-enhancing effects for social information (Guastella, Mitchell, \& Mathews, 2008; Hurlemann et al., 2010; Lieberman, 2012), providing additional evidence for these differences. In Sámi pedagogy, nonsocial factual and conceptual information is passed on during social interaction, pointing to the possibility of enhancing the recollection of these facts through the encoding of a social event.

The Sámi belong to the Finno-Ugric people, who arrived in Europe and northern Eurasia about 40,000 years ago. The regions in which the Sámi live expand north from central Norway and central Sweden through the northern parts of Finland to Russia's Kola Peninsula. The Sámi are recognized as an indigenous people in the Constitution of Finland, and they are allowed and encouraged to develop their languages and culture. Consequently, today, the most important role of the Sámi education system is revitalizing the Sámi languages and culture (Keskitalo, Määttä, \& Uusiautti, 2014). 
The need for a special pedagogy for the Sámi arises from the fact that the Western school system does not support the needs of the Sámi as an indigenous people. Sámi pedagogy can be seen as a culturally inclusive way to educate people in the context where Sámi language or culture is somehow present (Guttorm \& Keskitalo 2016). Therefore Sámi pedagogy does not involve only Sámi people; it is possible to use Sámi pedagogical approaches when educating other people living in the Sámi region. Sámi pedagogy needs to be developed on its own cultural basis. Consequently, the outer and inner factors influencing the culture need to be recognized and defined. The outer factors can be defined as historical and cultural burdens, while the inner factors are elements that give direction to education (Keskitalo, Määttä, \& Uusiautti, 2013).

Sámi pedagogy has three essential conceptions: time, place, and knowledge. The Sámi see time as sun-centered and bound to nature. Additionally, Sámi education is not bound to any building or classroom, which is the definition of the concept of "place." Finally, knowledge that is passed on needs to be useful in practice and readily shared with others. Knowledge, according to this pedagogy, results from negotiations and discussions (Keskitalo et al., 2012).

In the Circumpolar North above the Arctic Circle, the cultural background and ecological context of the indigenous people and their social learning traditions are at the epicenter of pedagogical approaches. Therefore, Arctic pedagogy is a valuable teaching tool in these regions. The goals, methods, and contents consider lifelong learning in the context of the Arctic, making it possible to study in the North. New technologies are used, especially Internet-based learning possibilities, as an attempt to combat the need to travel long distances to schools. The Arctic pedagogical teacher-hood naturally require technological skills for Internet-based learning environments. Moreover, teachers need to recognize their own and their students' individual strengths in every environment to support the students' learning in the best way possible; thus, pedagogical and social interaction skills are vital. This pedagogical approach sets the features of educational leadership; hence, educators and education authorities should act as supporters of, and motivators for, learners' positive development (Määttä \& Uusiautti, 2015). Arctic knowledge and practices are highly valued and embedded in the school subjects of Arctic pedagogy. In addition, visiting different local professionals is highly appreciated both by the students and by the communities, as the youth have the opportunity to see real working situations and the communities see that the Arctic skills are being maintained and passed on to the next generation. Individual strengths that are not just classroom-based are considered in every learning environment. The key terms for Arctic learning environments are inclusion, innovation, and spatiality. Nature is a learning environment, as is the Internet (Määttä \& Uusiautti, 2015).

There are similarities between the Sámi and Arctic pedagogies. For example, they both lean on the local curriculum. Another common issue is the boarding schools and dormitories used in the history of northern education. Boarding schools were the answer to the problem of the long distances between home and school that are a typical feature of the Arctic and Sámi areas. From the 
Sámi point of view, these boarding schools were a place of oppression and assimilation (Keskitalo et al., 2012), when generally the purpose was simply to offer education in the Arctic area. Today, avoiding the boarding school system is essential for the Arctic pedagogy. Instead of gathering people in one place for education, the Arctic pedagogy promotes new media platforms and new technologies (Määttä \& Uusiautti, 2015) through which students can study in their own homes, thereby offering an opportunity for virtual sociality. However, the Internet is a relatively new learning environment; hence, more research into ICT use in education, as well as online learning environments, is needed for the further development of such pedagogy.

\section{Research Context: Game Programming with Sámi Adolescents}

The aim of this study was to explore social learning in the Sámi cultural context in today's technologically oriented world for the further development of Arctic and Sámi pedagogies. Therefore, the research question sought information from teacher observers about social learning in the Sámi cultural context when using new media platforms. This question was as follows:

How do social interactions benefit learning in the Sámi cultural context when learning with and through ICTs?

Digital learning environments could have a digital árran-a digital campfire-representing the indigenous way of forming knowledge together. This could be achieved by developing Arctic and Sámi pedagogy and digital learning environments with consideration of the value of culture-based social learning. For example, the element of play and games in online learning could be studied and discussed in the indigenous context. Digital games are a remarkable cultural phenomenon of our age. According to Tampere University's game play barometer (Mäyrä, Karvinen, \& Ermi, 2016), up to $97.4 \%$ of the Finnish population plays games. It is a natural way to make social connections. Johan Huizinga first presented a theory about play and its role in culture in Homo Ludens: A Study of the Play-element in Culture (1949). According to Huizinga, the role of play is central to any form of human culture. Playing is also a typical feature in Sámi education (Keskitalo, 2010), and it can be considered a form of social interaction, growing, developing, and learning (Hyvönen, 2008; Kangas, 2010). New media platforms are already being used as learning tools in Arctic pedagogy. Technology can be used to preserve the culture as it already is and to create new cultural features, for example, through games. Therefore, the propagation of cultural content in social interactions during a game programming course is explored in this study.

The Utsjoki municipality is a bilingual municipality located in the Arctic area; it is the northernmost municipality of Finland. The data were collected through interviews with two teachers and one assistant about observations on a game programming summer course organized by the Utsjoki municipality and funded by EU funding from Leader Pohjoisin Lappi (Northernmost Lapland). The 
programming course was a purchased service that the University of Jyväskylä won after bids. Therefore, the teachers and the course materials were the same as in the courses taught in Jyväskylä. The aim of the course was to teach game programming to young people in the Sámi area through face-to-face lessons and to provide activities during summer vacation. The course took place at the Áilegas center in Utsjoki. Computers and other facilities were in place at the center.

Two programming students from the University of Jyväskylä, Finland, led the course, as they had done many times before in Jyväskylä. Although the geographical location of the course was different, no changes were made to the course content. The programming started at 9 a.m. every day, but it was possible for students to come as early as 8 a.m. Programming times were 9-11.30 a.m. and 12-3 p.m. The first course with this kind of programming syllabus was organized in Jyväskylä in 2009, and it has been offered every summer since then. The course was originally part of a game programming study done in Jyväskylä, whose aim was to research the effects of summer game programming courses and after school activities on students' interest in computer science and engineering studies.

Since they were not Sámi, it was not possible for the teachers from Jyväskylä to teach the course in the Northern Sámi language or cultural context. However, before the course, the Sámi cultural features were discussed with the teachers. The discussion was led by one of the researchers who is Sámi herself. The point of this discussion was to help the teachers to know their audience beforehand. For example, the teachers did not know that the Northern Sámi language is a common language in Utsjoki and used everywhere. A long discussion about the Sámi and the possible utilities of the Northern Sámi language and ICT was needed so that the teachers could understand the students better. Because the teachers arrived in Utsjoki only a day before the course began, the discussion took place during other course preparations.

The students in the programming course were chosen in sign-up order. There were a limited number of places $(n=10)$ in the course; the limiting factors were the number of laptop computers and the teacher capacity to guide the participants. Eleven students applied to the course. The course organizer decided to accept all the applicants to the course after discussions with the teachers and finding an extra laptop. Advertisements about the course had been published in a local magazine and on social media. The students of the programming course formed the group for observation. Due to their young age, some students had adult assistants with them. One assistant was able to speak with the students using the Northern Sámi language and thus was chosen to participate in this study. The 11 students came from Utsjoki, Inari, Enontekiö, and Vantaa. One student quit the course after the first day, leaving 10 students aged 6 to 17 years.

Seven students had Northern Sámi as one of their domestic languages that they used at home, and nine out of 10 had some Northern Sámi skills. The teachers' attitude toward the Sámi languages and culture was positive although they had little previous related knowledge. During the course, the teachers highlighted the fact that it was possible for students to use the Northern Sámi 
language in programming even though the teachers spoke Finnish and the programming language is universally English. The students were free to use any language in programming they felt comfortable with.

The programming environment was arranged so that the students were gathered around a big table and were face-to-face when working. This was a conscious choice and had a basis in the ways the Sámi share knowledge-the circular gathering around a campfire and real-life working situations that constitute scientific seminars for the Sámi (Keskitalo et al., 2012)—highlighting the social aspect of learning from and with each other. There are no authorities around the campfire; all are equals. Because this way of working and passing on knowledge is already a part of the Sámi culture, it was natural to transfer the campfire-style arrangement to a situation where ICT is used as a learning tool. The programming tools used in this course were Microsoft Visual Studio Community, the C\# programming language, and the Jypeli game engine created at Jyväskylä University. C\# is a programming language that supports a Unicode standard; thus, it is possible to program using the Northern Sámi language (Laiti, 2016).

The teachers explained that, usually, their first task is to show the topic at hand using a projector and then to help the students of the course. The only time the teachers are not around the table is the short period when they use the projector to show a new topic or feature to the students. After learning a new feature, the students usually try to fit it into their code, and they sometimes need help. At the beginning of the course, the need for the projector is greater, and at the end, the students usually need more teacher-student guidance because they know the basics and are trying to program independently. This, however, results in short periods when the role of the teacher is more typical, and the work is authority based. As mentioned, in Sámi culture, knowledge is not possessed by authorities; rather, it is held in common and results from negotiations (Keskitalo et al., 2012). This issue could have been solved by the teachers remaining in the circle with the students when they were teaching as well as using the projector. However, this was not possible because the projector was attached to a computer that could not be placed in the circle.

\section{Methodology}

Qualitative research is about understanding phenomena and creating a meaningful interpretation; hence, qualitative methods were used in this study. Furthermore, the processual nature of the phenomenon and the conceptual reflection are better characterized using qualitative methods (Creswell, 2009; Eskola \& Suoranta, 1998). The focus in this research was on subjective data. The data were collected using an online questionnaire with open-ended questions and included responses from both teachers and one assistant. The online questionnaire asked about their observations and thoughts during the programming course. The first author's researcher journal was also used as a tool for reflection and to confirm the consistencies in the observations. The first author 
wrote down observations when visiting the class during the week. The participating observation method was used because the first author made breakfast for the students every morning between 8 am and $9 \mathrm{am}$, in order to meet the students in an informal situation and as part of the course personnel. The participants did group themselves tightly, and it was impossible to stay outside the group. In this way, the researcher had first-hand experience with the participants. It was possible to record data to the researcher's journal as it occurred in the situation.

The assistant was chosen for the online questionnaire due to being the only multilingual assistant in the course who could speak both Finnish and Northern Sámi and thus linguistically able to observe the group. The online questionnaires were completed only in Finnish since this was the native language of the teachers and the assistant. The data were collected using Webropol, an online survey tool, to safeguard the participants' anonymity and give them the freedom to answer as honestly as possible. The teachers and the assistant played different roles during the course, so the questions were slightly different.

The questions for the teachers were the following:

1. What did you learn about the Sámi languages and culture during the course?

2. What types of challenges did you face during the course?

3. What went well in this course in your opinion?

4. Do you think that you would have benefited from knowing the Sámi languages and culture when teaching this course?

5. Do you have any other comments or observations regarding the course?

The questions for the assistant were as follows:

1. What went well in this course?

2. What was challenging for the students during the course?

3. How did the Sámi languages and culture appear in this course?

4. What types of observations did you make about the students during the course?

5. Do you have any other comments or observations regarding the course?

At the beginning of the online questionnaire, the teachers and assistant were guided and encouraged to answer the questions freely, stating whatever came into their mind. Open-ended questions were used to ensure broader answers. Hence, the teachers and the assistant were able to respond more extensively than specific questions would allow, generating honest and free comments on the issue of social interactions.

The sets of data were analyzed using qualitative content analysis (Creswell, 2009; Mayring, 2000) in which coding categories were derived from the data. Content analysis is a research method for studying documents and communication artifacts, which in this research are texts of various formats. Content analysis provides information about social learning in an indigenous ICT-based course as a phenomenon. In context analysis, the data are explored layer by layer categorizing, classifying, and dividing the data into themes. The process creates a complex picture of the research phenomena (Creswell, 2009; Mayring, 2000). 


\section{Ethical Issues and Limitations}

The research was conducted within the guidelines of the Finnish National Board on Research Integrity (TENK). The game programming course had students who were not competent to consent because they were under age. According to Finnish Act 1.4.1999/442 (Guardianship Services Act, 1999), a person is under guardianship until the age of 18 years. The Act also states that the guardian can decide on behalf of the person under 18 on a matter that the person cannot understand. In the case of this programming course, research permissions were sought from both the guardians and the students so that the observations of the teachers and assistant could be studied and analyzed.

The Ethical Conduct for Research Involving Humans (Canadian Institutes of Health Research, Natural Sciences, and Engineering Research Council of Canada \& Social Sciences and Humanities Research Council of Canada, 1998) states that if a study involves aboriginal or indigenous individuals, researchers should consider the interests of that group. Moreover, if the property or private information of the group is used, group leaders should be involved in the identification of the study participants, research analyses, or description of the characteristics of the group or individual participants representing the group (Canadian Institutes of Health Research et al., 1998).

This study dealt with the perceptions of teachers and assistant concerning social learning during the programming course. It will benefit the indigenous community (Keskitalo \& Sarivaara, 2016), as the results can provide much-needed information for the development of the Sámi community and its education.

The first author is Sámi herself, and hence, reflects strong attachments to the research. Her strength as a researcher arises from knowing Sámi language and culture as a member of indigenous Sámi community. This indigenous group membership makes her observing more natural for the students. Furthermore, the first and second author share a strong desire to find ways to develop pedagogies that benefit not only the Sámi people, but all people living in sparsely populated areas.

This study has certain limitations that should be acknowledged when evaluating the implications and results of it. Firstly, the study was small in scale, and the findings do not justify any direct conclusions as such. However, these findings encourage exploration of the possibilities of social interactions in indigenous ICT-based education. Humans are social beings, and social interactions have the power to bring significant learning improvement. The emotional charge of the learning event and the perceptual awareness of others in the learning process can have a significant effect on learning. Therefore, using and developing Arctic and Sámi pedagogies and their aspects of social interaction when learning with technology is of vital importance.

Secondly, the chosen method and approach may be considered a limiting factor, as this research did not gather the perspectives of the Sámi students 
themselves, but instead relied on the observations of teachers. However, getting the adults' perception of the developing group atmosphere has provided invaluable data. Thirdly, when using observation, it is possible that the participants see the researcher as an outsider or intruder in the situation. In the case of this research, there was no sign of that response among the students. However, it is possible that the researcher's observing skills can be inadequate (Creswell, 2009).

\section{Findings}

In Sámi pedagogy, the learning culture is based on social interaction and co-learning, meaning that learning occurs with and from each other (Keskitalo et al., 2014). Consequently, the student group started to form knowledge together. In the course environment, the group discussed their games and collaborated with each other and the teachers. The following observations are by the first author and the assistant, both fluent in Sámi language.

Kaikki olivat pelinteossaan yhdessä saman pöydän äärellä. Se ryhmäytti yhdeksi joukoksi, jossa oli monenlaista yhteistyötä naapurin kanssa tai pöydän yli. [Everyone was around one table while developing games. The students formed a collaborative group with a variety of co-operation with neighbor or over the table.]

The teachers were around the table most of the time and observed and advised the students. When the teachers were around, the students frequently asked for help. The students and teachers also collaborated in problem solving: for example, there was a problem with the Northern Sámi character set, but it was solved by working together. The teachers knew why the program was causing problems with the Sámi characters, and the students knew the Northern Sámi language utilities. Together, they came up with two solutions-changing the game engine code and changing the Northern Sámi text that was causing problems.

One of the assistants and most students used Northern Sámi when communicating during the course. They were initially hesitant in using the Northern Sámi language, due to the fact that many students do not necessarily speak Northern Sámi in their daily lives. There are several reasons for this: assimilation and the burden of transition, and different cultural background with friends and even family members. However, usage of the language increased toward the end.

Minä puhuin heidän kanssa saamea lähes koko ajan ja yleensä he vastasivat saameksi. Joskus joku ei ymmärtänyt ja kysyi, mitä tarkoitit. Sitten selitin suomeksi ja jatkoin saameksi. [I spoke Northern Sámi with them almost all the time and usually they replied in Northern Sámi. Sometimes someone did not understand and asked what I meant. Then I explained in Finnish and continued the discussion in Northern Sámi.]

The collaboration and discussion expanded to other environments. The students were mostly Northern Sámi-speaking youths living all over Finland. Cultural issues, such as reindeer herding, were not familiar to all the students. They started to collaborate and spontaneously discuss the Sámi culture while bonding as a group. 
Oli mielenkiintoista seurata oppilaiden keskusteluja ja missä tilanteissa he käyttivät suomea ja missä saamea. [It was interesting to follow student conversations and in what situations they used Finnish and where Northern Sámi.]

What is more, they learned from each other about cultural features.

Kerran esim. ruokailussa virisi keskustelu siitä, mitä porojen kanssa tehdään eri vuoden aikoina. [Once, for example, during lunch there was a conversation about what to do with reindeer during different seasons of the year.]

Based on the teachers' answers and observations reported in the online questionnaire, the teachers did not have previous knowledge about the Sámi languages or Northern Sámi. In addition, their cultural knowledge was lacking. After the course, the teachers knew some words and phrases in the Northern Sámi language, for example the fact that ellos Deatnu means "long live the river Teno." The teachers expressed the opinion that knowing Northern Sámi would have been beneficial for their teaching. They thought that if they could have taught programming in Northern Sámi, the source code of the games could have included more of the Northern Sámi language. In addition, the guidance would have been made easier if could have provided advice directly in Northern Sámi. The teachers could not understand, for example, how the assistant was advising the students and whether the advice was correct.

The teachers thought that the course was like all the other programming courses they had taught. The games were comparable to previous games made in the course, and the course structure was like that of previous courses as the busiest days were the last days of the course. However, two of the games that students made had instructions in the Northern Sámi language, and one had a basis in the cultural feature of salmon fishing.

Based on the teachers' online answers, they perceived the group as lively and positive, and they gave the students excellent feedback. The assistant thought that the group and teachers formed a harmonious ensemble, pointing to the importance of the positive social interaction among all concerned. The students got along well and helped each other, but they still did individual work and were quiet, so others could work, too. The teachers frequently encouraged the use of Northern Sámi in programming, especially in teacher-student interaction and particularly when the teachers sensed that the issue at hand was also languagerelated.

Jos ohjelmointikieli ei ole luotu omalla äidinkielellä, on mielestä suotavaa ja toisaalta tarpeellista että viljellään omaa kieltä niiltä osin kun se on mahdollista. Opetuksessa vaikuttaa varmasti, jos ohjattava kieli on oma äidinkieli, jolla ohjelmointia opetetaan. Tällöin kieleen kuuluvat erilaisuudet ja kulttuuri saadaan paremmin korostettua ja vahvistaa kielen identiteettiä. [If the programming language is not in your own native language, it is desirable as well as necessary to use your own language as far as it is possible. In teaching programming, it is certain that it has an effect if the 
teaching language is native to the teacher. In this way, the language and culture can be better emphasized and reinforced.]

\section{Discussion, Implications, and Future Research}

The aim of this research was to explore the social aspect of learning in a Sámi cultural context. The Sámi pedagogy respects the social learning traditions of the indigenous people. Learning together and discussing the issues at hand with each other are regarded as vital. The significance of the social aspect of learning has been confirmed in several empirical studies (Flynn, Turner, \& Giraldeau, 2016; Muthukrishna, Morgan, \& Henrich, 2016) outside the indigenous context, making it important to discuss it in indigenous learning environments as well. In Sámi pedagogy, factual and conceptual knowledge is passed on through non-formal interaction. This factor could have the potential to enhance learning and, consequently, the recollection of facts, since facts are connected to a social event. Moreover, social learning in cultural contexts involves people that share a common background. This interaction can occur vertically, involving the biological families passing along their knowledge to the next generation. However, even more significantly, social learning and cultural promotion occurs horizontally, with peers. (Gronow, 2017). During the programming course the students were around one table, making them a team whose members would easily cooperate with one another. During the teamwork and programming, the assistant and the first author observed how the students switched from Finnish to the Northern Sámi language and discussed not only programming issues but also specific cultural issues. The students may later be able to recall the issues and factors related to programming, as well as to reindeer herding, discussed during the course in connection with the social discussion. Furthermore, the assistant and the first author observed that culture is always present in game developing. Hence, it makes a difference who develops the game and in which context. These young students have grown up more or less within Sámi culture and within the sphere of influence of the main culture. The Sámi culture was not necessarily visible, but it was built into the structure of the games. In order to play the games they developed, one needed to understand the logic and the problem-solving strategies of the students. Therefore, if a Sámi person makes a game, players have to understand the Sámi way of thinking in order to master the game. By playing a game built in a certain cultural context, players can learn something more profound from that culture, far beyond cultural symbols.

During the game programming course, the students naturally observed and imitated the teachers when it came to programming, and they were motivated to do so to learn programming while using the Northern Sámi language. They were initially shy about using Sámi, but it soon became natural to speak it, as one of the assistants was continually using it. "Shared attention" refers to sharing a common attention component to facilitate learning, pointing to the multidimensionality of intersubjective learning. This naturally occurred during the course when students were paying attention to the teachers' presentations on new topics. Empathy and social emotions, in turn, indicate the human ability to feel compassion, which 
means that a person can take into consideration other people's perspectives and emotions. Hence, sociality is something natural to human beings (Dumontheil, 2015; Immordino-Yang, 2011; Lieberman, 2012; Meltzoff et al., 2009; Rumiati \& Humphreys, 2015). During the programming course, the students showed understanding of others' feelings by, for example, giving each other space to work in peace when needed without asking and helping each other when they realized that someone needed assistance. Had this course been online, would it have created this kind of spontaneous culture-based social learning and language revitalization? Arctic pedagogy, and especially online learning environments and distance-learning techniques, would benefit from this spontaneous knowledgeforming through discussion, which is typical of the Sámi pedagogy. Online and distance-learning platforms need a place for social interaction where the participants can exchange ideas and discuss what is on their minds. Hence, this specific element of sociality and togetherness, which is at the core of Sámi pedagogy, should be supported, and its possibilities should be explored and broadened in digital learning environments as well.

New media platforms are ubiquitous, and they are part of our everyday lives. It is said that technology is a two-edged sword: it can be useful in preserving language and culture, but it can also do the opposite and assimilate small languages and cultures (Allen, Resta, \& Christal, 2002). The question may be raised as to whether this is a so-called wicked problem (Rittel \& Webber, 1973), where, due to complex interdependencies and social complexity, the effort to solve one aspect of the wicked problem reveals or creates another. The Arctic pedagogy's emphasis on avoiding dormitories and offering online learning environments as a solution to the need to travel long distances may create a new platform for assimilation instead of revitalization, since online social interaction is different from face-to-face interaction, or where social connection can even be lost completely. Arctic pedagogy would benefit from further research, especially when online education in the Arctic involves indigenous people. Furthermore, most online learning environments are in English, and naturally using one's own language facilitates the understanding and learning of an issue as well as a feeling of connection to the issue.

The purpose of this course was to teach programming, but it was organized in such a manner that it simultaneously gave an opportunity to revitalize the Sámi language through social factors. It was beneficial that the course was organized in the traditional way of gathering students together around one table. Everyone learned in the process: the teachers learned about the Sámi languages and culture, and the students learned about programming and making games. A digital campfire (digital árran in Northern Sámi) was created: the collaboration during the course not only helped in problem solving, but also created new information about merging Sámi languages and computer software.

In this study, the Northern Sámi language and culture found its way into the games when the games were created in a Sámi cultural context. This dimension points to the many possibilities of technology: developing games in similar circumstances could even recreate indigenous storytelling in the form of digital 
games and link the storytelling generation to younger generations. Today, there are educational projects such as Skins, a digital storytelling workshop for aboriginal youth. In the workshops, indigenous game designers and developers teach how to make digital games out of the indigenous stories. Their aim is to encourage indigenous people to be producers of new technology. Together, they are forming a digital árran-the indigenous people as cultural consultants, university graduates as technical advisors, and indigenous youth as storytellers. However, they are not doing this online. If we can create a syllabus that promotes online learning and indigenous ways of forming knowledge, it will be possible to see online courses revitalizing the Sámi languages and culture through social aspects of learning.

\section{References}

Allen, N., Resta, P. E., \& Christal, M. (2002). Technology and tradition: The role of technology in Native American schools. Techtrends, 46(2), 50-55.

Balto, A. (1997). Samisk barneoppdragelse i endring [Sami childhood education in change]. Oslo, Norway: Ad notam Gyldendal.

Battiste, M. (2002) Indigenous knowledge and pedagogy in First Nations education. A literature review with recommendations. Ottawa, ON: Apamuwek Institute. Retrieved from https://bit.ly/2LIHOId

Boling, E., Hough, H., Krinsky, H., Saleem, H., \& Stevens, M. (2011). Cutting the distance in distance education: Perspectives on what promotes positive, online learning experiences. Internet and Higher Education, 15(2), 118126.

Canadian Institutes of Health Research, Natural Sciences and Engineering Research Council of Canada, \& Social Sciences and Humanities Research Council of Canada. (1998). Tri-Council policy statement: Ethical Conduct for Research Involving Humans. Retrieved from https://bit.ly/2xxNjqk

Creswell, J. W. (2009). Research design. Qualitative, quantitative, and mixed methods approach. Los Angeles, CA: Sage.

Dubinsky, J. M., Roehrig, G., \& Varma, S. (2013). Infusing neuroscience into teacher professional development. Educational Researcher, 42(6), 317329. doi:10.3102/0013189X13499403

Dumontheil, I. (2015). Development of the social brain during adolescence. Psicología Educativa, 21(2), 117-124. doi:10.1016/j.pse.2015.08.001

Eskola, J., \& Suoranta, J. (1998). Johdatus laadulliseen tutkimukseen [Introduction to qualitative research]. Tampere, Finland: Vastapaino.

Flynn, E., Turner, C., \& Giraldeau, C. (2016). Selectivity in social and asocial learning: Investigating the prevalence, effect and development of young children's learning preferences. Philosophical Transactions of the Royal 
Society B, Biological Sciences, 371(1690), 1-8. doi:10.1098/rstb.2015.0189

Gronow, A. (2017). Pään sisällä vai ihmisten välisissä yhteyksissä? Kulttuurin leviäminen sosiaalisissa verkostoissa [In the head or in human relationships? The spread of culture in social networks]. In A. Gronow \& T. Kaidesoja (Eds.), Ihmismielen sosiaalisuus [Socializing mind] (pp. 76-103). Tallinn, Estonia: Gaudeamus.

Guardianship Services Act. (1999). Retrieved from http://www.finlex.fi/en/laki/ kaannokset/1999/en19990442.pdf

Guastella, A. J., Mitchell, P. B., \& Mathews, F. (2008). Oxytocin enhances the encoding of positive social memories in humans. Biological Psychiatry, 64(3), 256-258.

Guttorm, M., \& Keskitalo, P. (2016). Opetushenkilöstön työkalupakki: Moninainen koulu Suomen saamelaisalueella [Tools for education professionals: Multifaceted school in the Sámi region of Finland]. Utsjoki, Finland: Utsjoen kunta.

Hernández-García, Á., González-González, I., Jiménez-Zarco, A. I., \& ChaparroPeláez, J. (2015). Applying social learning analytics to message boards in online distance learning: A case study. Computers in Human Behavior, 47, 68-80.

Huizinga, J. (1949). Homo ludens: A study of the play-element in culture. London, UK: Routledge \& Kegan Paul.

Hurlemann, R., Patin, A., Onur, O. A., Cohen, M. X., Baumgartner, T., Metzler, S., ... Kendrick, K. M. (2010). Oxytocin enhances amygdala-dependent, socially reinforced learning and emotional empathy in humans. Journal of Neuroscience, 30(14), 4999-5007.

Hyvönen, P. (2008). Affordances of playful learning environment for tutoring playing and learning (Doctoral dissertation). University of Lapland.

Immordino-Yang, M. H. (2011). Implications of affective and social neuroscience for educational theory. Educational Philosophy and Theory, 43(1), 98-103. doi:10.1111/j.1469-5812.2010.00713.x

Kangas, M. (2010). The school of the future: Theoretical and pedagogical approaches for creative and playful learning environments (Doctoral dissertation). University of Lapland.

Keskitalo, P. (2010). Saamelaiskoulun kulttuurisensitiivisyyttä etsimässä kasvatusantropologian keinoin [Cultural sensitivity in the Sámi school through educational anthropology] (Doctoral dissertation). Dieđut. Guovdageaidnu, Norway: Sámi allaskuvla.

Keskitalo, P., Määttä, K., \& Uusiautti, S. (2013). Saamelaispedagogiikan aika [Time for Sámi pedagogy]. Yhteiskuntapolitiikka, 78(1), 99-104.

Keskitalo, P., Määttä, K., \& Uusiautti, S. (2014). Saamelaispedagogiikan peruspiirteet [The characteristics of Sámi pedagogy]. In P. Keskitalo, S. 
Uusiautti, E. Sarivaara, \& K. Määttä (Eds.), Saamelaispedagogiikan ydinkysymysten äärellä [The core issues of Sámi pedagogy] (pp. 89-109). Rovaniemi, Finland: Lapland University Press.

Keskitalo, P., \& Sarivaara, E. (2016). The definition and task of mediating Sámi research. In S. Uusiautti \& K. Määttä (Eds.), The basics of caring research (pp. 119-136). Rotterdam, Netherlands: Sense Publishers.

Keskitalo, P., Uusiautti, S., \& Määttä, K. (2012). How to make the small indigenous cultures bloom? Special traits of Sámi education in Finland. Current Issues in Comparative Education, 15(1), 52-63.

Laiti, O. (2016). Ethnoprogramming: An indigenous approach to computer programming: A case study in Ohcejohka area comprehensive schools (MSc thesis). University of Lapland. Retrieved from http://urn.fi/URN:NBN:fi:ula-201612021380

Lieberman, M. D. (2012). Education and the social brain. Trends in Neuroscience and Education, 1(1), 3-9. doi:10.1016/j.tine.2012.07.003

Lipina, T.V., \& Roder, J.C. (2013). Co-learning facilitates memory in mice: A new avenue in social neuroscience. Neuropharmacology, 64(1), 283-293. doi:10.1016/j.neuropharm.2012.06.054

Mayring, P. (2000). Qualitative content analysis. Forum Qualitative Sozialforschung / Forum: Qualitative Social Research, 1(2). Retrieved from http://www.qualitative-research.net/index.php/fqs/article/view/1089/2385

Määttä, K., \& Uusiautti, S. (2015). The basics of arctic pedagogy. Global Journal of Human-Social Science: G Linguistics \& Education, 15(4), 28-34.

Mäyrä, F., Karvinen, J., \& Ermi, L. (2016). Pelaajabarometri 2015 - Lajityyppien suosio [Game play barometer 2015-The popularity of genres]. TRIM Research Reports 21. Tampere, Finland: University of Tampere. Retrieved from http://urn.fi/URN:ISBN:978-952-03-0153-8

Meltzoff, A. N., Kuhl, P. K., Movellan, J., \& Sejnowski, T. J. (2009). Foundation for a new science of learning. Science, 325(5938), 284-288. doi:10.1126/science.1175626

Muthukrishna, M., Morgan, T. J. H., \& Henrich, J. (2016). The when and who of social learning and conformist transmission. Evolution and Human Behavior, 37(1), 10-20. doi:10.1016/j.evolhumbehav.2015.05.004

Rasi, P. M., Keskitalo, P. P. K., \& Rasmus-Moilanen, E.-L. (2016). Árktalaš pedagogihka ovddieamen: Arktista pedagogiikkaa kehittämässä [Developing Arctic pedagogy]. Kide: Lapin yliopiston tiede - ja taidelehti, 3, 4.

Ratcliffe, M. (2006). Phenomenology, neuroscience and intersubjectivity. In H. Dreyfus \& M. A. Wrathall (Eds.), A companion to phenomenology and existentialism (pp. 329-345). Maiden, MA: Blackwell Publishing.

Rittel, H., \& Webber, M. (1973). Dilemmas in a general theory of planning. Policy Sciences, 4(2), 155-169. 
Rumiati, I. R., \& Humphreys, G. W. (2015). Cognitive neuroscience goes social. Cortex, 70, 1-4. doi:10.1016/j.cortex.2015.07.008

Skins workshops on Aboriginal storytelling in digital media. Retrieved from http://skins.abtec.org/

Smith, L. (1999). Decolonizing methodologies: Research and indigenous peoples. London, UK: Zed Books.

\section{Author Contact}

Outi Kaarina Laiti: outi.laiti@gmail.com

Faculty of Education, University of Lapland, PL 122 96101, Rovaniemi, Finland

Satu-Maarit Frangou: satu-maarit.frangou@ulapland.fi

Faculty of Education, University of Lapland, PL 122 96101, Rovaniemi, Finland 